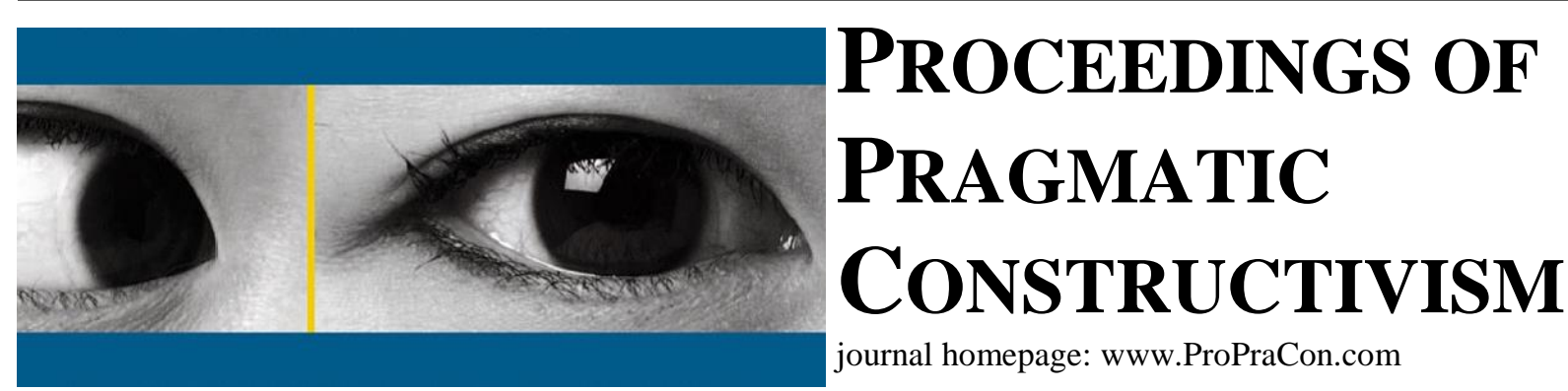

\title{
New rules of research? - Report from the post-modern university
}

\author{
Lars Bo Henriksen \\ Professor, PhD. Department of Planning, Aalborg University \\ lbh@plan.aau.dk
}

\begin{abstract}
When the university Marxists in the 1970s wanted to have 'research for the people' as an alternative to research for research (art for art's sake), they could hardly imagine that this claim would, in the future, be changed to 'research for profit'. This change from 'research' to 'research for profit' has had severe consequences for the research community, for the universities and, most importantly, for research in general - for the research process and for the criteria for legitimising and evaluating what is, or is not, good research. In this paper I investigate the present conditions for conducting university research through a case study of external partners buying research at the university - 'The Beef Report'. I do this through investigating different conceptions of science and research - romantic, modern and postmodern - in arguing that today's university is a post-modern university (Lyotard, 1979), and that this post-modern university poses very significant new problems for both research and researchers.
\end{abstract}

\section{Introduction}

'Die Wissenschaft denkt nicht'

Martin Heidegger, 1954

\subsection{Scene 1 - Research report redrawn}

13 August. In a news feed from DR (Denmark’s Radio) one reads that 'Alcohol, coffee and candy are greater climate sinners than beef'. A report published by Aarhus University, Department of Agroecology, stated that meat from cattle is less damaging to the climate, had less CO2 emissions than alcohol, coffee and candy. Problem was, however, that there were serious methodological problems in this report, but that was not the only problem; far from it. The report had a sponsor, The Danish Agriculture and Food Council, Denmark's largest agricultural lobby organisation, but the council did not only pay for the report, the council had also designed the problem statement. The researchers behind the report saw no problems in this, as the agricultural council had nothing to do with the report itself. This, however, did not deter other researchers from criticising the report, both for its methodological shortcomings and for the close connection to the agricultural council (Information, 13 August, 2019).

16 August. The report is subject to serious criticism from other researchers - they call it totally useless. 'They (the researchers behind the report) just smashed a report together, uncritically, based on some old figures and vastly different studies. You cannot do that'. 'It's completely off the dial to do it that way'. It also turned out that the report was funded by a subsection of the agricultural council called 'Kvægafgiftsfonden' (Literally meaning 'The Livestock 
Tax Fund'). The purpose of the fund is to '... strengthen the beef sector and the development and competitiveness of cattle farming’. (Information, 16 August, 2019).

22 August. Again, the methods underpinning the report are questioned and again it is deemed useless. (Information, 22 August, 2019).

30 August. The Socialist People's Party and The Red and Green Alliance, both part of the new government's parliamentary basis, demand that the new minster for research and education act and request Aarhus University for an explanation about this report. 'I am shocked. This is a deeply principled case ...' says a representative from the Socialist People's Party. 'Very scary, that there are no better practices for how to collaborate with those who put money into research. It completely calls into question the credibility of science, when direct party interests can be allowed to interfere. This must be prevented', says a representative from The Red and Green Alliance. So, now it is not just a matter of questioning methods and a discussion between researchers; it has become a political matter and a representative case of the validity, reliability and credibility of research in general. It also turns out that the agricultural council has not only sponsored and designed the problem statement for the report, but also decided the layout and the pictures etc. of the final report (Information, 30 August, 2019).

30 August. The new minister for research and education decided to act. In a letter to the Aarhus University rector she writes, 'The university must protect the university and the individual researcher's freedom of research and the ethics of science. It is a crucial condition for researchers to maintain their integrity and credibility in the social debate, and that there is no doubt about the independence of research'. In the letter she also demanded a presentation of the case from the university. (Information, 30 August, 2019).

30 August. It now turns out that employees from the agricultural council and from Danish Crown (Denmark’s largest slaughterhouse organisation) are co-authors on the project, but not credited as such; this is correctly termed a breach of good scientific practice. 'This is a mess' one of the critics said. 'A breach of the Vancouver declaration' said another. The contributions from the agricultural organisations amounts to whole sections of the report. Even if other researchers criticise this fact heavily, the researchers behind the report continue to maintain that this is independent research.

(Information, 30 August, 2019).

30 August. The rector from Aarhus University says that 'The so-called beef report from the University of Aarhus cannot be called independent research. There is no reason to be proud of that. The process is simply critical'. In the interview with the newspaper the rector says that he has asked for a presentation of the case from the department responsible for the report and indicates that he might consider redrawing or redrafting the report. (Information, 30 august, 2019).

2 September. The agricultural council admits that they had gone too far in the case of this report. 'We can see that we have not adhered to good practice for collaboration with universities, as we should have done. We have gone too far and our involvement in the project has discredited the researchers' results. We can't do that. Therefore, we choose to repay the amount used to the fund that gave us the money in the first place'.

2 September. In a letter to the editor, one of the researchers behind the report defends the report and says that the newspaper behind the critical articles has misread the report and not fully understood its content. The report is the victim of an unfair media campaign.

2 September. The University withdraws the report. 'It does not meet the standards set by the university regarding independent research as well as good research practice and dissemination of research. We have therefore chosen to withdraw the report. We cannot live with such conditions casting doubt on the integrity of the university and the procedures will now be tightened up'. Says the head of the research centre in a press release. (Ritzau, 2 September, 2019).

4 September. In a newsletter Aarhus University informs us that the head of the department responsible for the report has resigned and left the university 'by mutual agreement'. 'There has not been the necessary arm's length maintained for external stakeholders, which calls into question the University's independence and integrity. This is completely unacceptable', says the dean of The Science and Technology Faculty in the newsletter. 'It is the department management ... who has overall responsibility for research and collaboration'. 'The department management therefore had to ensure the overall framework for the project before the work was started, as well as in the execution, in the 
quality assurance and independence of the report. I must conclude that this responsibility has not been satisfactorily fulfilled’. (Information, 4 September, 2019).

Days in September. In the early days of September editorials and letters to the editors in several newspapers continued the debate about this report. This debate fell into two camps: the first camp was about climate change (Jyllands Posten, 8 September, 2019), the second camp was about the influence of external partners and sponsor's role in the research process, about research ethics and about the conditions for doing research in today's university in general (Information, 7 September; 2019. Hoffman, 2019; Budtz Petersen et al, 2019; Scavenius, 2019).

11 September. Aarhus University in reply to the Minister of Research: 'We deeply regret the progress of this report'

\subsection{Scene 2. - Another Rector on the future of universities}

The rector (vice chancellor) of Aalborg University noted in a newspaper interview in early 2018, 'The future of universities is more competition. Humboldt's days are finally over, and those who wish to go back are lost unhelpfully in the past' (Appel, 2018b). In the interview he touched upon the new rules and roles of the university, so the interview was conducted around such themes as economy and the new conditions for doing research. 'Of course, it was a fundamental paradigm shift when (the university) went from the century-old Humboldt's collegiate system to one more inspired by private business'.

In 2003 a new university law abolished the century old collegial management system and replaced it with new system with a board of directors appointed by the ministry. This board then appoints the rector, who then appoints deans, with deans appointing heads of departments etc. The rector, in the interview, is clearly not particularly in favour of the old system. 'But it (the Humboldtian university) was an outdated system that was not agile and not designed for a modern world where change is happening much faster. The system was unable to match the need for quick decisions or execution on things right here and now'. He then continues to say that there is a great need for, and a strengthened focus on, knowledge and research from the political system, the business community and from different interest groups. This is in order to ensure that Denmark can continue as a rich and competitive welfare society.

One of the management's primary tasks, according to the rector, is to create a playing field for the employees within the economic and political framework that is decided in Parliament. However, in recent years the financial framework has been considerably narrowed. Among other things, with the so-called re-prioritisation - meaning that all budgets are cut by two percent every year. Even if the rector would like to see that the constant cuts in budgets for research and education would cease, he also admits that the scarcity of resources can only be handled by a professional management system. 'It would have split the university's faculty if the old system had to handle such budget cuts'.

However, the current economic problems must also be viewed in the context of the changes that took place in 2007 when parts of the sector research institutions were placed under the universities. Sector research institutes were state-owned independent research institutes under various Danish government ministries, whose primary task was to do research, development and consultancy in various fields. This meant that the tasks of delivering a knowledge base for government and ministry decisions was now also a university responsibility. At the same time, a new political paradigm emerged that emphasised usable and potentially commercialisable research - commonly called 'From research to invoice' (Ministry of research, 2003). 'The old system of professional and academic interests in the management team would have no opportunity to resist the pressure (from the government)' the rector believes.

This change in university management and the new tasks following the merger with the sector research institutes was followed by a lot of controversy. Some meant that the focus on business and commercialisation would mean that the universities would lose their independence and thereby also their freedom of research in this new system of scarce resources and competition (Andersen, 2017a; Andersen, 2018a; Sørensen, 2018; Appel, 2018a). The rector’s response: 'We, as universities, must of course be wary of this, but it should be borne in mind that each year Danish universities receive 8 billion DKK from the state in basic funding for research; most without any explicit conditions attached to this funding'. But still, international competition between Danish and foreign universities has intensified in recent years, according to the rector. On the one hand, the struggle to attract the most talented researchers is difficult work, and on the other hand to gain access to the much sought-after research funding. And he continues, 'The only university that will survive in the future is the university that is doing well in competition in the international arena. It is important for us because knowledge is a commodity out there. We don't get anything if we don't deliver too'. 'Denmark spends one percent of GDP on research each year. Aalborg University receives just over 10 percent of the total Danish basic research grants, and that is not enough for the university to compete in international competition', says the rector. 
'Therefore, researchers will have to go out and seek external funding in the fight against international research environments as well'. This demand for external funding creates some markedly higher demands on university researchers as they are measured not only by their results but also by their ability to generate revenue and bring external funding 'home' to the university while also delivering high quality research-based teaching.

\section{Which university?}

The two scenes described above demand answers to a simple question; is the case of the withdrawn report a consequence of the changed status of the university? Have the quest for resources, the intensified competition and the constant budget cuts anything to do with the sad case of the withdrawn 'beef report'? That is, is this just a case of sloppy researchers, not knowing how to do proper research, or is there something seriously awry in the system that made them come up with a report that the university management had to withdraw? I will seek to attempt to address this question through an investigation of different conceptions of science and research and the status of the university romantic, modern and post-modern - in plausibly claiming that today's university is a post-modern university with different roles and rules than those previously expected from a university.

There is, no doubt, a certain aura around words such as 'university', 'professor', 'research', 'science' etc. and a lot of effort has, over the years, been expended to guard this aura. Professors are smart, wise and knowledgeable and universities are serious places where new scientific discoveries are made and the knowledge emanating from such universities is true, valid and reliable. At least, that is the popular conception of professors, science and universities. But there are several different conceptions of professor, science and university and their respective roles in society. In the following I describe these conceptions as three distinct ideal types, romantic, Humboldtian or modern, and post-modern and in connection to each description I take a closer look at the rules and roles of such universities.

\subsection{The university - Romantic, modern, post-modern}

The romantic conception of the university is very similar to the popular conception. The professor is a lone genius who thinks great thoughts, but is also distractedly hopeless when it comes to more practical tasks; the caricature of the absent-minded professor. We know this figure very well from popular culture. The university is, it is said, a very serious place and distant from society; a secluded and tranquil place (the ivory tower) where professors can think their grandiose thoughts. One very precise description of this romantic conception is found in Whyte (1956) where he fiercely argues against what he calls 'organisation man' - also the title of his book - and organisation man's 'social ethic'. This social ethic informs organisation man, or we could call him bureaucrat, that he should organise research in the same manner as any other bureaucratised organisation in a modern industrial society - be it the post office, state bureaucracy, the army or any other state-run organisation. This means plans, strategies, layers of bureaucratic hierarchies, and researchers organised in research groups working on projects with a specific aim. That is, researchers are, according to Whyte, only working on projects aimed at applying already known knowledge and not necessarily trying to make new discoveries. Contrary to this bureaucratic menace Whyte seems to favour a very romantic image of research which looks very much like the public image mentioned above. A lone genius working on basic research in what Whyte calls 'idle curiosity’ and 'purposelessness ...' (Whyte, 1956, pp. 208 - 209).

Whyte's romantic university is, for the most part, described in negative terms in contrast to the bureaucratised university. The lone genius working on new discoveries in idle curiosity would hardly be concerned with mundane problems such as the climate footprint of beef production. Instead he (yes, it is most often a he) would be concerned with much more basic problems. If he then made a report which the university later would have the recall, then it would probably just be a problem for the individual researcher and his own reputation and not for the university - as it was just an individual fault of a clearly nutty professor. And money would hardly be involved in this anyway as Whyte’s romantic university would be funded generously by the state and possibly also by alumni.

Even if this is a romantic conception Whyte seems to have made some relevant points in terms of basic research, bureaucratisation, and the emphasis on research projects with a specific goal. So, even if his critique seems valid enough, it is doubtful if we can return to the days of the lonely genius - that is, if they ever really existed. The dream, though, still exists, in popular culture, in press and in everyday conversations and maybe also as an available scapegoat for advocates of the post-modern university (see e.g. Information, March 17, 2018). Worse still is the fallacy of the system, as no one can hold the lone genius responsible for his actions. History is replete with cases of this type of research-set-up producing dubious results. Lysenkoism exists.

The modern university then? The modern university is modelled after Humboldtian ideals. Some have denounced the Humboldtian university and charged it with being lost in the past (see above). Why is that? The university, in this Humboldtian narrative, is a cornerstone in a modernisation project. According to Schanz (1992), 
modernity is characterised by its rationalism, anti-traditionalism and scientism; that is, particularly knowledge production and society in general should be based on principles of rational scientific knowledge, and not on traditional or religious beliefs, and thereby secure the disenchantment and secularisation of society. The university plays a central role in this modernisation process, because it is here that new, valid and trustworthy knowledge is produced - or discovered, as it might be called. The criterion for good and valid knowledge is based on secure scientific principles. New knowledge should be laid out into the open accessible to anyone and the knowledge produced is a common good that belongs to everyone and preferably also has been through a thorough peer review process. But such validity is also secured by what Lyotard (1979) calls the grand narratives - e.g. enlightenment, democracy or critique - meaning that knowledge production is allowed as long as the results of that production remain within the scope of the grand narratives. The principles of Humboldtian knowledge production is secured by an institutional setup including generous government funding, tenure, and self-government as a professional bureaucracy.

The Humboldtian university is the classical university. Free research, unity of research and teaching and governed by the professors in a kind of democratic manner (Madsen, 2009; Fink, 2013). Many universities are inaugurated in this image and many today are still governed by these principles - at least in principle. For example, the Aalborg University strategy plan, 'Knowledge for the World', is through and through, conducted along the lines of Humboldtian principles (Aalborg University, 2016). The basic idea was to create space and time for research, freed from outside interests, be it religious, state governed or commercial. Employment was supposed to be through tenure, that is a system of permanent employment to secure the freedom of the researchers, so no one from outside or inside the university could threaten the researchers with unemployment, no matter what their research results would show, no matter how unpleasant the truth found might be for those in power, be it religious or secular (Madsen, 2009, pp. 64; Andersen, 2017a).

These are the key principles, and in many instances, this has worked very well and still does in certain parts of the world. The Humboldtian university has produced many great results over the years. However, the Humboldtian university was not without its problems. During the 1960s more and more students were allowed into the universities and the increased numbers resulted in problems of all kinds. Some of them were rather trivial in terms of time and space, others of a more principled character, as when the students demanded to be represented in the governing bodies. This combined with the protest against the Vietnam war, the baby-boomers etc. led to university reforms and, to a very large degree, these reforms could be justified. The universities were not able to cope with the increased number of students, and in many instances the universities had become complacent with little or no contact to the real world outside. Inside the university there were challenges as well. Nepotism, researchers not doing anything, sloppy teaching and in all a very tranquil culture where not much was happening - at least this was the image often presented to the public. Things had to change and change came fast, as the rector in scene 2 noted above. The question is whether this university could produce research reports that the university would have to recall? Of course, it could, but the report in question would probably have been produced in one of the sector research institutions mentioned above and not by the university. If the university had produced such a report it is foreseeable that it would have ended up in a committee and a process of endless meetings would have started. The end result would probably be to blame the individual researcher and not the university department. And no one would have been laid off as the researchers would be tenured staff and it is possible that no one would ever even have noticed?

\subsection{The post-modern university}

The Post-modern university is quite different (Lyotard, 1979; Strohl, 2006; Wolfe, 1996; Madsen, 2009) - in this respect the rector quoted above is perfectly right. With the 2003 university law, and the merger with the sector institutions in 2007, the conditions for knowledge production changed completely at Danish universities. The main idea was to change from a self-governed professional bureaucracy to a new public management (NPM) inspired machine bureaucracy, meaning that the university should now have a more efficient and effective management, just like the rector is arguing for in the interview above (Pianezzi et al., 2019). There are several reasons for this change. The university is no longer an elite institution for the few, but has become a mass university. The universities, as knowledge producers, have become an important player in the development of late-modern states. With these changes and new roles for the university, the old self-governed university was deemed too slow and unable to prioritise according to the needs of society and especially the state and private enterprise. Another more sinister reason could be that the state bureaucracy wanted to have a firmer grip on the universities as foreseen by Whyte in 1956. This was, for the most part, especially for budgetary reasons and an attempt to change the universities in their own bureaucratic image - a serious case of systems colonising life worlds. The change in management, which, as said, resembled an NPM machine bureaucracy, was followed by other fundamental changes. Tenure was replaced by temporary positions for the scientific staff, freedom of research was replaced by commissioned research grants and, following this, the no longer so generous government funding was replaced by a form of market driven research. 
No one has described post-modern knowledge production as precisely as Lyotard (1979). Back in the 1970s Lyotard was asked to provide an account on the then present state of knowledge at that time and the result was the book 'The post-modern condition - a report on knowledge'. His basic idea was that the rules of knowledge production, the ways that knowledge is legitimised, have changed from a modern way of legitimisation to a post-modern one. Where the modern way of legitimisation emphasised progress and emancipation - the grand narratives, the post-modern way emphasised efficiency and profit. That is, the university can no longer legitimise its existence and its knowledge production by pointing to man's emancipation from prejudice and superstition, but now has to produce knowledge that is immediately saleable in a marketplace. Knowledge has simply become a commodity as the rector noted above. This new way of knowledge production is followed by a series of measures that should secure the efficiency of the system. No tenure and layoffs of scientific staff whenever it was deemed necessary according to the budgets, research for profit, knowledge as a commodity and science as a productive force. This could not and cannot go on unnoticed and researchers would resist what they saw as a system which compromises freedom of research (Sørensen, 2017; Andersen, 2017a). Also, the integrity of the researcher is endangered, as when criteria for good research is changed from research-internal criteria - e.g. reliability and validity - to research-external criteria - bureaucratic and commercial - or as the rector put it: 'Researchers ... are measured not only by their results but also by their ability to generate revenue and bring external funding 'home' to the university'. In an attempt to defend their professional integrity, researchers resisted and the state bureaucracy had to force these changes through. Or as Lyotard puts it:

'The decision makers ... allocate our lives for the growth of power. In matters of social justice and of scientific truth alike, the legitimation of that power is based on its optimizing the system's performance - efficiency. The application of this criterion to all of our games necessarily entails a certain level of terror, whether soft or hard: be operational (that is, commensurable) or disappear (Lyotard, 1979).'

This commensurability is secured by bureaucratic measuring systems - BFI in Denmark or the Hirsch index or something similar - the idea being that bureaucrats without proper scientific training should be able to evaluate research without knowledge of the research process or the ability to evaluate research results. Problematic, of course, and Lyotard provides some very good reasons as to why:

'Determinism is the hypothesis upon which legitimation by performativity is based: since performativity is defined by an input/output ratio, there is a presupposition that the system into which the input is entered is stable; that system must follow a regular 'path' that it is possible to express as a continuous function possessing a derivative, so that an accurate prediction of the output can be made. (Lyotard, 1979, p. 106).

It is now somewhat obvious that the postmodern university could produce a report that had to be withdrawn because the external partners were coming too close to the research process and replacing proper science with input favourable their own vested interests. With the extreme focus on external funding such incidents become almost inevitable.

In what follows I take a closer look at some of these reasons. Generating funds means new criteria for research, commercial criteria as stated by both Lyotard and the rector in his interview. This means that researchers now spend a lot of time applying for external funding and negotiating projects with commercial partners outside the university. It also means that the specific research themes are decided by commercial interests and not solely by scientific interests. This means that applied research will take precedence over basic research. Whyte, from his romantic position in 1956, describes this situation very precisely:

'... scientists would now concentrate on the practical application of previously discovered ideas rather than the discovery of new ones (Whyte, 1956)'.

With the post-modern commercialisation of research, it is more valuable for the parties involved - be it researchers, university management or businesses - to sell and buy known and well-tested problem-solving, than embarking on new and insecure projects. This is solving of practical problems, applying known solutions to known problems, and the neglect of more fundamental problems that could prove even more vital in the future, that is, new solutions to new problems (L. Nørreklit, 1978; H. Nørreklit, 1991. p 38; Henriksen et al., 2004, p 145). The focus on generating revenue for the budgets also jeopardises research in general and forces researchers to take on projects simply for the sake of generating revenue. There is a very sinister reason for this, as the researcher's employment is based on precisely this ability to generate revenue. And with the lost tenure this becomes even worse:

'Job security, tenure, is a condition of freedom of research. Researchers must be free to choose the research area, publish and comment on their research results and on the conditions at their institution. They have a duty to make their knowledge available to the public and to participate in the public debate. The university should encourage them to do so (Andersen, 2017a, p. 273).' 
Andersen's Humboldtian statement points to the fact that lost tenure not only has dire consequences for the individual researcher, but also for the freedom of research in general. When researchers are forced to take on commercial projects and have others outside the university make their problem statements and decide which research projects to take on, then it becomes quite obvious that researchers are caught between a rock and a hard place. They can either take on the commissioned research and generate revenue for the university, but at the same time risk jeopardising research criteria such as validity, reliability and transparency, or they could maintain their professional integrity and defend the classical research criteria, refuse to take on the commissioned research project, and lose their job. There is no excuse, however, for producing research reports that the university will later on have to withdraw for reasons of poor research quality. But the withdrawn report can be explained by drawing on the concept of the present post-modern condition, even if it cannot be excused or absolved.

Above we noted that the minister of research, in a very Humboldtian statement - almost similar to the one from Andersen - said that 'the university must protect the university and the individual researcher's freedom of research and the ethics of science. It is a crucial condition for researchers to maintain their integrity and credibility in the social debate, that there is no doubt about the independence of research'. In the case of the withdrawn report this is quite obviously not the case. When the report became a case of media attention and the scandal unfolded in the days of late September and early October, the rector of the university reacted by blaming the individual researchers and sacking the department head; notably, he did not mention his own system which demanded research for profit. And the question is whether the university that should be 'a playing field for the employees within the economic and political framework that is decided in the Parliament' can, at the same time, live up to the minister's expectations, when it also has to abide with external interests' demands, be they commercial, governmental or any other outside partner. This points to the role of university management in all of this debacle. Sørensen (2017) blamed the university rectors and their organisation for being way too obsequious to the demands of politicians and not defending university freedom and the freedom of research. Andersen (2017b) follows this by saying, 'the universities' management has looked upwards to catch the signals coming from above - and try to adapt to them. There is no incentive to listen to what the researchers might say'. If Sørensen and Andersen are right, this could explain why professional university management and even the minister for research on the one hand has defended, or at least not tried to change, a postmodern system with research for profit and then, on the other hand, when the scandal broke out, blaming the researchers and the head of the department that they did not work along the lines of a classical research paradigm - 'The university must protect the university ...' and 'the so-called beef report from the University of Aarhus cannot be called independent research. There is no reason to be proud of that. The process is simply critical'. The question is how researchers should be able to serve both masters both the commercial as well as the internal research criteria? Neither the rector, nor the minister, can have both independent research and research for profit. It looks like they expect this to be possible, but they do not have a system capable of supporting these very contrasting expectations.

\section{Conclusions}

The change from the Humboldtian university to the post-modern university has had severe consequences for the research process. Even if the new professional university management pretend that nothing has changed in the research process itself, it is evident that it has most certainly changed. Such incidents as the withdrawn report strongly suggests that there is crisis in the world of research. The status of the university has changed and, if this is the case, it could have dire consequences for knowledge production in general and especially for universities and their researchers. The particular example discussed here surely indicate that this is now probably the general case. The commercialisation, the bureaucratisation, research as a productive force and knowledge as a commodity, combined with lost tenure, has led to a change in both the rules and the role of the university. And these facts appear to be capable of now plausibly explaining the existence of the withdrawn report. It seems that the merger of the universities and the sector research institutions was not a case of the sector institutions getting university status, but instead that the universities became sector institutions conducting commissioned research. 


\section{Literature}

Andersen, Heine (2017a). Forskningsfrihed - Ideal og virkelighed (Freedom of research - Ideal and reality). Hans Reitzel.

Andersen, Heine (2017b). Seks rektorer afviser interview om forskningsfrihed (Six rectors reject interview on research freedom). Magisterbladet, November 8, Danish Association of Masters and PhDs.

Andersen, Heine (2018). Forskningsfriheden er i dyb krise (Freedom of research is in deep crisis). Altinget, 22 February.

Appel, Morten (2018a). Universitetet - mellem folket, fakturaen og friheden (The university - between the people, the invoice and the freedom). Nordjyske, 21 January.

Appel, Morten (2018b). The future of universities is more competition. Nordjyske, 28 January.

Center for Vild Analyse (Centre for Wild Analysis (a weekly column)) (2018). Hvis universiteterne skal bevare deres formål, må de genfinde deres formålsløshed. (If universities are to maintain their purpose, they must regain their futility). Information, March 17.

Fink, Hans et al. (2003) Universitet og videnskab: universitetets idéhistorie, videnskabsteori og etik. (University and Science: The university's history of ideas, science theory and ethics). Hans Reitzel, København.

Henriksen, Lars Bo et al. (2004) Dimensions of Change - Conceptualising reality in organizational research. CBS Press. Copenhagen.

Hoffman, Thomas (2019). Oksekødsrapport: Aarhus Universitet har gjort det før - men det har andre også. (Beef report: Aarhus University has done it before - but so have others). Videnskab.dk. September 6.

Information (2019) Serie on the 'Beef report' https://www.information.dk/serie/oksekoedsrapporten?Ist_srs=

Jyllands Posten (2019). De militante vil erobre klimadebatten. (The militants will conquer the climate debate) (08.09.2019)

Lyotard, Jean-Francois (1979). The Postmodern Condition: A Report on Knowledge. Manchester University Press.

Madsen, Mogens Ove (2009). Universitetets død - kritik af den nyliberale tendens (The death of the university - critique of the neoliberal trend). Frydenlund.

Ministry of Research, (2003). Nye veje mellem forskning og erhverv - fra tanke til faktura. (New roads between research and business - from thought to invoice).

Nørreklit, Hanne (1991). Virsomhedens problemerkendelse (The company's problem recognition). DJØF forlag.

Nørreklit, Lennart (1978). Problemorienteret forskningspraksis og den reale virkeligheds konstitution. (Problem oriented research practice and the real realities constitution). Skriftserie for videnskabsteori ved Aalborg Universitetscenter. nr. 4.

Pianezzi, Daniela et al (2019) Academia after Virtue? An inquiry into the Moral Character(s) of Academics. Journal of Business ethics.

Ritzau (2019). Aarhus Universitet trcekker omstridt oksekødsrapport tilbage (Aarhus University withdraws disputed beef report). 2 September.

Scavenius, Theresa (2019) Bag skandalerne står projekt-universitetet (Behind the scandals is the project university). Ingeniøren, 5 september.

Schanz, Hans-Jørgen (1990). Forandring og balance. Modtryk. 
Strohl, Nicolas M. (2006) The postmodern university revisited: reframing higher education debates from the 'two cultures' to postmodernity. London Review of Education. Vol. 4, No. 2, July.

Sørensen, Christen (2017) Magtens arrogance er uendelig - også hos universitetsledelser (The arrogance of power is endless - even with university leaders). Information, 4 December.

Whyte, William H. (1956) The Organization Man. Simon and Schuster, New York.

Wolfe, Alan (1996) The Feudal Culture of the Postmodern University. The Wilson Quarterly. Vol. 20, No. 1 (Winter), pp. 54-66

Aalborg University (2016). Knowledge for the World - Strategy 2016-2021. Aalborg University. 